\title{
Characterisation of Solid Mine Wastes Produced during Iron Ore Mining and Processing and their Potential Environmental Impacts
}

Francis Xavier ( $\sim$ fgitau26@gmail.com )

Taita Taveta University College: Taita Taveta University https://orcid.org/0000-0001-8276-4829

\section{Research Article}

Keywords: Iron Ore, Mine Wastes, Mining, Environmental Impact, Geochemistry, Mineralogy

Posted Date: March 15th, 2021

DOl: https://doi.org/10.21203/rs.3.rs-302151/v1

License: (1) (1) This work is licensed under a Creative Commons Attribution 4.0 International License.

Read Full License 


\section{Abstract}

Solid waste deposited on the surface acts as a potential source of environmental pollution. High concentration of toxic elements in solid mine wastes can pose serious environmental risks. This study aims at characterising solid mine wastes produced due to iron ore mining and processing for their geochemistry and mineralogy. Samples were collected using a stratified sampling strategy. X-ray Fluorescence (XRF), X-ray Diffraction (XRD), and Petrographic analysis techniques were used. XRD analysis revealed a high abundance of Hematite (29\%), with low amounts of Quartz stockpile samples. Berlinite (33\%) amounts were high in waste dump samples, where Quartz was in high concentrations $(34 \%)$ in the overburden samples. XRF analysis revealed a high amount of iron in the stockpile and waste dump, while Silica was highest in the overburden. Petrography analysis revealed major minerals in the solid mine waste: magnetite, Hematite, and Quartz with traces of mica, olivine, feldspar, and biotite. The minerals were characterised by a lamellar structure with mutual grain boundaries. Sulfide minerals that may cause acid drainage and various heavy metals were in considerable amounts. These elements have the potential of causing adverse environmental impacts hence the need for such characterisation to devise mitigation strategies and rehabilitation.

\section{Introduction}

The characterisation of mineral and processing wastes is a key step during mining operations to mitigate risks associated with these wastes (Jamieson et al. 2015). This is made possible by providing appropriate remediation and waste management schemes. This characterisation help reveal the nature of the mine wastes and their potential interactions with the ecosystem (Hudson-Edwards and Dold 2015).

In the recent past, iron ore has been extracted in sedimentary rocks in different parts of the world over a long period (Lascelles 2011). Iron ore occurs as magnetite $\left(\mathrm{Fe}_{3} \mathrm{O}_{4}\right)$, Goethite $(\mathrm{FeO}(\mathrm{OH}))$ and Hematite $\left(\mathrm{Fe}_{2} \mathrm{O}_{3}\right)$ (Shrimali et al. 2016). Iron ore has very vast usage across the globe that makes it an essential commodity in industrialisation that has been continuously sought through mining (Cheneket 2018).

Mining of iron is associated with various mineral processing operations such as blasting, grinding, and magnetic separation, which results in the production of various solid mine wastes (Ferreira and Leite 2015).

According to Bett et al. (2016), significant iron ore deposits have been found in Marimanti in Tharaka Nithi County, Kitui County, Migori County, and Taita Taveta County, among other many areas.

Mine wastes constitute the largest percentage of any wastes produced by various industrial activities (Suleman and Baffoe 2017) \& (Lottermoser and Lottermoser 2003).

In mining and mineral processing operations, mining wastes are sub-economic materials that contain low cutoff grades or do not contain any ore mineral (Lottermoser and Lottermoser 2003). 
Mining operations, metallurgical extractions, and mineral processing produces various gaseous, liquid, and solid wastes. These are generated in different processes during mining, mineral processing, and metallurgical operations, as shown in Fig. 1.

During open pit mining and development, various mine wastes such as waste rocks, spoils, overburden, atmospheric emissions, and mine water may be emitted (Ferreira and Leite 2015). Mineral processing activities produce various processing wastes such as tailings, stockpiles of less grade materials, sludges, milling water, and emissions (David Meehan 2012).

The chemical and physical characteristics of mine wastes may vary in relation to the geochemistry and mineralogy of the resource, the size of the crushed mineral particles, processing chemicals, materials handling method, method and type of blasting techniques utilised, and the processing technology used (Jamieson et al. 2015), (Jelenová et al. 2018) and (Amos et al. 2015).

During materials handling at any mine, about $70 \%$ of the material handled is waste whose geochemical properties may be equivalent to the ore mined (Jamieson 2011). According Nordstrom (2011), drainage chemistry results from iron sulfide minerals oxidation such as pyrite, whose reaction generates acidity and various sulfates.

Most of the environmental challenges are associated with various mine wastes and their capability to react chemically with the water and air (Jamieson 2011). To carefully understand these reactions involved, it shall be needful to characterise the solid mine wastes in order to determine their geochemistry and mineralogy. This shall be done using XRD, XRF, and Petrographic techniques.

\section{Research Methodology}

\section{Study Area}

This study was conducted within the Samrudha Resources Iron Ore mining area in Taita Taveta County, Kenya. This area lies approximately $450 \mathrm{~km}$ southeast of Nairobi and $250 \mathrm{~km}$ northwest of Mombasa, at between $3.1^{\circ} \mathrm{S}$ and $3.3^{\circ} \mathrm{S}$, and $38.1^{\circ} \mathrm{E}$ and $38.3^{\circ} \mathrm{E}$, as shown in Fig. 2. The mine covers $20 \mathrm{~km}^{2}$ and neighbors Tsavo National Park on the east and farmlands on the west. The mining of iron ore has been taking place in this area since the early 2008's (Maranga et al. 2013). The site lies within the Mozambique belt, geologically rich in industrial minerals such as iron ore and manganese (Siljander et al. 2019).

\section{Materials and Equipment}

Equipment and materials used in this study include a Laboratory jaw crusher, pulveriser, X-Ray Diffractometer (Roller 2011), X-ray Fluorescent (XRF) machine (Langhoff et al. 2006), petrological microscope (Dias et al. 2020), and solid mine waste samples.

\section{Sample Collection}


Stratified sampling strategy was employed in sample collection to allow replication and representation with the number of increments determined per ISO 3082 (ISO 2017). Sampling pits were dug, and the samples were collected and stored in Khaki bags. Approximately $200 \mathrm{~g}$ of each sample were taken and stored in well-labeled khaki bags sealed and ferried to the laboratory for preparation and analyses.

\section{Sample Preparation}

Representative rock samples (each $200 \mathrm{~g}$ ) were dried in an oven at $120^{\circ} \mathrm{C}$ to a constant weight in a furnace and then allowed to cool at room temperature. The samples were homogenised then pulverised to 200 microns.

\section{Elemental Analysis}

Pulverised sample $(50 \mathrm{~g})$ for each designate was mixed with $5 \mathrm{~g}$ of flux starch, and the resultant mixture was mixed in a mortar and pestle. The resulting mixture was made into pellets using a hydraulic press. The pellets were fed into the XRF machine for analysis.

\section{Mineralogical Analysis}

Mineralogy was determined using both X-Ray Diffraction (XRD) and Petrological analysis. For the XRD, samples of 50 grams were pulverised to fine sizes of between 30 to $50 \mu \mathrm{m}$ following procedures outlined by Knorr and Bornefeld (2005). For qualitative evaluation and homogenisation of various mineral components, the samples were ground to pass through a $45 \mu \mathrm{m}$ mesh and then placed on the sample holder for analysis using Bruker A.X.S. D2 phaser SSD16 and relevant plots done by Difrac Eva software.

For petrological analysis, $30 \mathrm{~mm}$ samples were cut from the whole samples using a diamond cutter. The samples were mounted onto glass slides, ground using a grit series $(400,600 \& 800)$, and then covered with a slide for analysis using Fein Optic Polarizing Light Microscope.

\section{Results And Discussion}

\section{Elemental Analysis of the Solid Mine Wastes}

\section{Waste Dumps}

The results for elemental analysis for waste dumps are shown in Table I. The results indicated that all samples had higher amounts of $\mathrm{Fe}_{2} \mathrm{O}_{3}$ than other elements, with WD1 recording the highest amount. Silica was also in moderate amounts. Other elements such as Thorium, Chromium, and Vanadium were identified in traces.

Table I: XRF analysis for Waste Dump (W.D.) samples 


\begin{tabular}{|lllllll|}
\hline $\begin{array}{l}\text { Element/ } \\
\text { Compound }\end{array}$ & $\begin{array}{l}\text { Chemical } \\
\text { Formula }\end{array}$ & $\begin{array}{l}\text { WD1 } \\
\text { Mass \% }\end{array}$ & $\begin{array}{l}\text { WD2 } \\
\text { Mass \% }\end{array}$ & $\begin{array}{l}\text { WD3 } \\
\text { Mass \% }\end{array}$ & $\begin{array}{l}\text { WD4 } \\
\text { Mass \% }\end{array}$ & $\begin{array}{l}\text { Average } \\
\text { Mass \% }\end{array}$ \\
\hline Iron & $\mathrm{Fe}_{2} \mathrm{O}_{3}$ & 51.35 & 33.96 & 39.66 & 34.70 & 39.92 \\
\hline Silica & $\mathrm{SiO}_{2}$ & 29.10 & 49.50 & 38.56 & 26.33 & 35.87 \\
\hline Manganese & $\mathrm{MnO}$ & 5.91 & 1.17 & 0.26 & 1.42 & 2.19 \\
\hline Barium & $\mathrm{Ba}$ & 4.62 & 0.19 & 0.10 & 0.25 & 1.29 \\
\hline Titanium & $\mathrm{TiO}^{2}$ & 2.88 & 0.17 & 0.24 & 0.51 & 0.95 \\
\hline Aluminum & $\mathrm{AlO}_{3}$ & 1.73 & 0.49 & 1.10 & 1.83 & 1.29 \\
\hline $\begin{array}{l}\text { Calcium } \\
\text { Carbonate }\end{array}$ & $\mathrm{CaCO}$ & 1.60 & 12.97 & 19.07 & 33.43 & 16.77 \\
\hline Sulphur & $\mathrm{S}$ & 1.50 & 0.16 & 0.00 & 0.10 & 0.44 \\
\hline Phosphorous & $\mathrm{P} \mathrm{O}_{5}$ & 1.10 & 1.25 & 0.89 & 1.26 & 1.13 \\
\hline Nickel & $\mathrm{Ni}$ & 0.05 & 0.02 & 0.02 & 0.01 & 0.03 \\
\hline Zinc & $\mathrm{Zn}$ & 0.04 & 0.01 & 0.01 & 0.03 & 0.02 \\
\hline Copper & $\mathrm{Cu}$ & 0.03 & 0.01 & 0.00 & 0.01 & 0.01 \\
\hline Lead & $\mathrm{Pb}$ & 0.03 & 0.01 & 0.01 & 0.01 & 0.02 \\
\hline Bismuth & $\mathrm{Bi}$ & 0.02 & 0.01 & 0.00 & 0.01 & 0.01 \\
\hline Chromium & $\mathrm{Cr}$ & 0.00 & 0.08 & 0.05 & 0.02 & 0.04 \\
\hline Thorium & $\mathrm{Th}$ & 0.00 & 0.00 & 0.02 & 0.01 & 0.01 \\
\hline Vanadium & $\mathrm{V}$ & 0.00 & 0.00 & 0.00 & 0.04 & 0.01 \\
\hline
\end{tabular}

Heavy metals were present in the waste dump samples. High amounts of iron ore identified in waste dump samples inferred high dilution during mining. Only high-grade iron ore is mined at Samrudha resources mine; therefore, ore that is highly diluted with gangue minerals (Silica) is disregarded as waste. The waste dumps, which are generally the blasted material, contain chemical elements such as Sulphur that may be potential environmental pollution agents.

\section{Stockpiles}

The stockpiled materials result shown in Table Il contains iron ore of low grade and iron ore fines from the processing operations at the mine.

Table II: XRF analysis for Stockpile (S.P.) samples 


\begin{tabular}{|lllllll|}
\hline $\begin{array}{l}\text { Element/ } \\
\text { Compound }\end{array}$ & $\begin{array}{l}\text { Chemical } \\
\text { Formula }\end{array}$ & $\begin{array}{l}\text { SP1 } \\
\text { Mass } \%\end{array}$ & $\begin{array}{l}\text { SP2 } \\
\text { Mass } \%\end{array}$ & $\begin{array}{l}\text { SP3 } \\
\text { Mass \% }\end{array}$ & $\begin{array}{l}\text { SP4 } \\
\text { Mass \% }\end{array}$ & $\begin{array}{l}\text { Average } \\
\text { Mass \% }\end{array}$ \\
\hline Iron & Fe2O3 & 88.75 & 71.94 & 76.92 & 84.53 & 80.54 \\
\hline Silica & SiO2 & 5.85 & 19.37 & 16.31 & 11.86 & 13.35 \\
\hline Aluminium & AlO3 & 1.73 & 1.90 & 1.65 & 1.40 & 1.67 \\
\hline $\begin{array}{l}\text { Calcium } \\
\text { Carbonate }\end{array}$ & CaCO3 & 0.83 & 1.29 & 0.82 & 1.11 & 1.01 \\
\hline Phosphorous & $\mathrm{P} 205$ & 0.79 & 1.06 & 0.98 & 0.64 & 0.87 \\
\hline Barium & $\mathrm{Ba}$ & 0.62 & 0.96 & 1.27 & 0.05 & 0.73 \\
\hline Titanium & $\mathrm{TiO}$ & 0.56 & 0.90 & 1.03 & 0.00 & 0.62 \\
\hline Sulphur & $\mathrm{S}$ & 0.26 & 0.63 & 0.00 & 0.00 & 0.22 \\
\hline Manganese & $\mathrm{MnO}$ & 0.26 & 1.67 & 0.58 & 0.24 & 0.69 \\
\hline Bismuth & $\mathrm{Bi}$ & 0.10 & 0.04 & 0.07 & 0.10 & 0.08 \\
\hline Nickel & $\mathrm{Ni}$ & 0.05 & 0.07 & 0.21 & 0.08 & 0.10 \\
\hline Rubidium & $\mathrm{Rb}$ & 0.05 & 0.02 & 0.04 & 0.03 & 0.04 \\
\hline Lead & $\mathrm{Pb}$ & 0.04 & 0.04 & 0.05 & 0.04 & 0.04 \\
\hline Copper & $\mathrm{CuO}$ & 0.04 & 0.02 & 0.02 & 0.02 & 0.03 \\
\hline Zinc & $\mathrm{Zn}$ & 0.03 & 0.02 & 0.01 & 0.02 & 0.02 \\
\hline Zirconium & $\mathrm{Zn}$ & 0.00 & 0.00 & 0.01 & 0.00 & 0.00 \\
\hline Vanadium & $\mathrm{V}$ & 0.00 & 0.00 & 0.00 & 0.02 & 0.01 \\
\hline
\end{tabular}

The stockpile samples contained very high amounts of $\mathrm{Fe}_{2} \mathrm{O}_{3}$ and low amounts of other elements. SP1 and SP4 samples were iron ore fines; despite having high amounts of iron ore concentration, the material is unwanted and is therefore waste. These fines are stockpiled near the processing plant for disposal. The other stockpiled materials (SP2, SP3) are low-grade iron ore, and small size $(50 \mathrm{~mm})$ float iron occurring alluvially in the area. These materials are currently not utilised by the mining company and contain potential environmental pollutants, as revealed in the XRF analysis in Table III.

\section{Overburden}

The overburden material, most abundant in the area, generally consists of a mixture of topsoil and rocks either blasted or dozed off during access to the ore before blasting operation.

Table IV: XRF analysis for Overburden (OB) samples 


\begin{tabular}{|lllllll|}
\hline Element/ Compound & Chemical Formula & OB1 \% & OB2 \% & OB3 \% & OB4 \% & Average \% \\
\hline Silica & $\mathrm{SiO} 2$ & 57.83 & 60.7 & 24.93 & 20.62 & 41.02 \\
\hline Iron & $\mathrm{Fe} 2 \mathrm{O3}$ & 15.01 & 8.63 & 6.1 & 19.92 & 12.415 \\
\hline Potassium & $\mathrm{K} 20$ & 10.36 & 15.98 & 0.37 & 0.58 & 6.8225 \\
\hline Calcium Carbonate & $\mathrm{CaCO3}$ & 7.42 & 1.76 & 62.86 & 52.54 & 31.145 \\
\hline Aluminium & $\mathrm{AlO3}$ & 6.13 & 9.48 & 3.11 & 3.32 & 5.51 \\
\hline Phosphorous & $\mathrm{P} 205$ & 1.83 & 1.8 & 1.7 & 1.47 & 1.7 \\
\hline Titanium & $\mathrm{TiO}$ & 0.51 & 0.69 & 0.67 & 0.76 & 0.6575 \\
\hline Barium & $\mathrm{Ba}$ & 0.38 & 0.24 & 0.17 & 0.19 & 0.245 \\
\hline Sulphur & $\mathrm{S}$ & 0.25 & 0.37 & 0.1 & 0.01 & 0.1825 \\
\hline Manganese & $\mathrm{MnO}$ & 0.05 & 0.08 & 0.39 & 0.48 & 0.25 \\
\hline Chromium & $\mathrm{Cr}$ & 0.05 & 0.06 & 0.03 & 0.02 & 0.04 \\
\hline Zirconium & $\mathrm{Zr}$ & 0.04 & 0.04 & 0.01 & 0.02 & 0.0275 \\
\hline Strontium & $\mathrm{Sr}$ & 0.03 & 0 & 0.04 & 0.04 & 0.0275 \\
\hline Rubidium & $\mathrm{Rb}$ & 0.03 & 0.04 & 0 & 0 & 0.0175 \\
\hline Copper & $\mathrm{CuO}$ & 0.02 & 0.01 & 0.02 & 0.01 & 0.015 \\
\hline Zinc & $\mathrm{Zn}$ & 0.01 & 0.01 & 0.01 & 0 & 0.0075 \\
\hline
\end{tabular}

These materials are generally rich in $\mathrm{SiO}_{2}$ and $\mathrm{CaCO}_{3}$ with impurities in the form of chemical elements that may cause environmental impacts, as shown in Table IV.

\section{Mineralogical Analysis of Solid Mine wastes}

XRD technique was successfully used to reveal the different phases that the solid mine wastes presented. These results are shown in Figs. 6, 7, and respectively. The mass percentages for each element/compound are shown in Tables VI, VII, and VIII. A representative sample for the stockpile, waste dump, and overburden was analysed.

\section{Stockpile Sample}

From XRD analysis, the predominant crystalline element in the stockpile samples is hematite $\left(\mathrm{Fe}_{2} \mathrm{O}_{3}\right)$ and magnetite $\left(\mathrm{Fe}_{3} \mathrm{O}_{4}\right)$. Quartz and iron were in low amounts. This is because the ore has already been processed; therefore, it contains low amounts of gangue minerals.

Table Vl: Composition of elements in the stockpile sample 


\section{Waste Dump}

\begin{tabular}{|lll|}
\hline Element/Compound Name & Formula & $\%$ \\
\hline Hematite & $\mathrm{Fe}_{2} \mathrm{O}_{3}$ & $29.0 \%$ \\
\hline Magnetite & $\mathrm{Fe}_{3} \mathrm{O}_{4}$ & $21.1 \%$ \\
\hline Manganosite & $\mathrm{MnO}$ & $16.6 \%$ \\
\hline Berlinite & $\mathrm{Al} \mathrm{O}_{4} \mathrm{P}$ & $11.6 \%$ \\
\hline Calcite & $\mathrm{Ca} \mathrm{CO}_{3}$ & $10.8 \%$ \\
\hline Quartz low & $\mathrm{Si} \mathrm{O}_{2}$ & $6.3 \%$ \\
\hline Iron & $\mathrm{Fe}$ & $4.5 \%$ \\
\hline
\end{tabular}

Quartz $\left(\mathrm{SiO}_{2}\right)$ and Berlinite were in high amounts in the waste dump samples. Magnetite and Braunite minerals were in low amounts. The waste dumps generally contain unwanted minerals such as Quartz, causing the magnetite mineral, which contains iron ore, to be identified in low amounts.

Table VII: Composition of elements in the waste dump sample

\begin{tabular}{|lll|}
\hline Compound Name & Formula & $\%$ \\
\hline Quartz & $\mathrm{Si} \mathrm{O}_{2}$ & $42.7 \%$ \\
\hline Alite & $\mathrm{AlPO}_{4}$ & $23.0 \%$ \\
\hline Nitratine & $\mathrm{Ca}_{3} \mathrm{O}_{5} \mathrm{Si}$ & $13.4 \%$ \\
Hematite & $\mathrm{N} \mathrm{Na} \mathrm{O}_{3}$ & $6.9 \%$ \\
Calcite & $\mathrm{Fe}_{2} \mathrm{O}_{3}$ & $5.1 \%$ \\
Magnetite & $\mathrm{Ca} \mathrm{C} \mathrm{O3} 3 \mathrm{O}_{4}$ & $3.9 \%$ \\
Braunite & $\mathrm{Mn} 2+\mathrm{Mn} 3+6[08 \mid \mathrm{SiO} 4]$ & $1.8 \%$ \\
\hline
\end{tabular}

\section{Overburden}

Berlinite $\left(\mathrm{AlPO}_{4}\right)$ and Quarts $\left(\mathrm{SiO}_{2}\right)$ revealed high phases in the overburden samples. Hematite and Calcite minerals were in low amounts. The presence of berlinite and quartz minerals in abundance revealed that all the materials from the overburdened material is disregarded as waste.

Table VIII: Composition of elements in the overburden sample 


\begin{tabular}{|l|lll|}
\cline { 2 - 4 } & Compound Name & Formula & $\%$ \\
\hline Berlinite & $\mathrm{AlPO}_{4}$ & $32.5 \%$ \\
\hline Quartz low & $\mathrm{Si} \mathrm{O}_{2}$ & $31.2 \%$ \\
\hline Retgersite & $\mathrm{NiSO}_{4} \cdot 6 \mathrm{H} 20$ & $14.7 \%$ \\
\hline Goethite & $\mathrm{FeO}(\mathrm{OH})$ & $6.7 \%$ \\
\hline Alite & $\mathrm{Ca}_{3} \mathrm{O}_{5} \mathrm{Si}$ & $6.5 \%$ \\
\hline Hematite & $\mathrm{Fe}_{2} \mathrm{O}_{3}$ & $5.9 \%$ \\
\hline Calcite & $\mathrm{CaCO}_{3}$ & $2.5 \%$ \\
\hline
\end{tabular}

The petrographic analysis was done on the solid mine wastes to study the transparent composition of these samples. Both cross-polarised light (X.P.L) and plane-polarised light (PPL) were applied to identify the samples' minerals. Petrography microscopy analysis results are shown in Figs. 9, 10,11, 12, and 13.

The thin section of stockpile (SP2) sample (Fig. 9) consists of Magnetite, Pyro - Garnets Quartz, Biotite, and Hematite. The dark opaque visible colour in the thin sections is the magnetite. The whitish colour indicates the biotite iron ore and bands of quartz assuming different shades. The brownish-grey colour indicates martitized magnetite in the sample hence occurring as Hematite.

A thin section of the waste dump sample (Fig. 10) shows a dominant opaque dark grey colour, indicating traces of magnetite and the rust-like colours of brown-red iron hydroxide (Hematite). The white - pink colour indicates the quartz. Feldspar is structured in a network with intrusions of quartz. There are olivine, biotite, and Zircon minerals appearing in between mineral grains of magnetite.

In Fig. 11, magnetite is the dominant mineral. It is occurring as opaque; however, hematite occurring as a brownish colour. The solid waste is characterised by specula and simple lamellae texture with mutual grain boundaries between various individual mineral intrusions suggesting that the minerals break along the grain boundaries.

The overburden material sample generally occurs, and needlelike crystals of feldspar with inclusions of quartz, mica, and shades of pyroxene as viewed in Fig. 12.

Sample of stockpile (SP1) (Fig. 13) contains high amounts of magnetite and hematite minerals occurring as opaque and brown shades. There are traces of gangue minerals such as quartz, pyroxene, garnet, and olivine minerals in the sample. The occurrence of the individual grains which are well-formed exhibit resistance to weathering. Grain boundaries also separate different minerals with varying sizes without individual grains interlocking. When exposed to various atmospheric conditions such as meteoric water 
and air, this phenomenon indicates that the minerals may react at a higher rate. Therefore, toxic chemical elements pose a high risk to the environment in the event of a reaction.

\section{Conclusion}

Most of the environmental impacts of iron ore mining and processing are associated with the subsequent release of various toxic elements from the mine wastes produced. These mine wastes tend to pose serious problems, not because of the volumes produced but also the areal extents and coverage. Due to the continuous pollution and contamination, solid mine wastes from iron ore mining must be isolated and treated to reduce oxidation, erosion, toxicity, or dumped waste in well-designed waste dumps. Uncontrolled disposal of solid mine wastes can be associated with increased turbidity in various water sources and the release of harmful chemical elements, which may also be acidic (Bernd G. Lottermoser 2011). These contaminants travel through the soil, water, biosphere, and atmosphere to cause environmental impacts. Most of the adverse environmental effects caused by solid mine wastes are their tendencies to chemically react with available water or air hence producing contaminants (Jamieson 2011). These contaminants may also be inhaled or ingested by humans and react with fluids in the body (Kirsimäe 1999). Airborne dust and winds may also cause transportation of these chemical elements present in the solid mine waste to soils and surface water.

Minerals and chemical elements in solid mine wastes may occur as sulfide minerals, non-sulfide minerals such as carbonates, secondary minerals formed by chemical weathering such as goethite, and chemical compounds produced by ore processing as oxides produced through the leaching process (Jamieson 2011).

There is a presence of considerable amounts of Sulphide minerals such as Helvine $\left(\mathrm{Be}_{3} \mathrm{Mn}^{2+}{ }_{4}\left(\mathrm{SiO}_{4}\right)_{3} \mathrm{~S}\right)$ and Sphalerite (ZnS) in the stockpile and waste dump samples. Exposure of these sulfide elements to an oxygenated environment, surface runoff, and groundwater will cause the sulfides to be oxidised and produce acid waters that can be sources of contaminants such as heavy metals and metalloids. When these sulfide minerals are exposed to the oxidising atmosphere, they become unstable chemically (Parbhakar-Fox et al. 2018). During this process, chemical weathering reactions are initiated due to a lack of equilibrium with the environment. Therefore, weathering proceeds aided with various microorganisms present, meteoric waters, and atmospheric gases (Bernd G. Lottermoser 2011). Iron ore fines stockpile is at the highest risk. This is because of its increased surface area, subsequently increasing its potential for exposure to oxidation and weathering. Petrography analysis also revealed poorly crystalline samples with structural defects that contained distorted crystal lattice. This eventually leads to building up stresses in the rock structure, making the mineral susceptible to chemical attack. The mine wastes also contain phosphates, silicates, oxides, hydroxides, carbonates, and halides that can pose an environmental problem.

\section{Recommendations}


Due to the adverse impacts of solid mine wastes produced during iron ore mining, reducing their environmental and health impacts would require proper management, skills, and expertise. These include a characterisation of all solid wastes in terms of their geochemistry and mineralogy. Understanding the solid mine waste interactions to the various condition can be of key benefit to the mining company.

The following are practical ways that can be done to minimise and reduce the environmental impacts caused or likely to be caused by solid mine wastes:

\section{Beneficiation of Low-Grade Iro Ore}

Low-grade iron ore that is disregarded as waste could be beneficiated further to avoid causing environmental pollution if dumped as waste. The beneficiation method could include using bio floatation techniques and gravity concentration (Rea et al. 2015) \& (Bett et al. 2014).

\section{Utilisation of Iron Ore Dust in Cement Companies}

Iron ore dust can also be sold to Cement Manufacturing Companies. This provides an alternative ready alumina-silicate raw material that is more effective and reactive than normal clinker (Luo et al. 2016).

\section{Phytoremediation}

Plants can be used to clean up contaminated environments. Restoration of dense vegetation cover can physically stabilise these solid mine wastes dumped and help reduce the pollution of the chemical elements. Different species of plants that can adapt to the atmospheric condition in the area, such as Leucaena leucocephala (Leucaena), can absorb chemical elements (Ssenku et al. 2017). This plant species accumulates heavy metals and produces large amounts of biomass, therefore a potential plant for phytoremediation (Ssenku et al. 2017).

\section{Conventional Remediation}

Conventional methods of remediation of areas where the mine wastes are located majorly focus on physical and chemical stabilisation. This entails covering up the solid mine wastes with innocuous material, generally soil or rocks from other sites, to reduce wind and water erosion. However, this may only offer a temporary solution. Complete removal of the material and soil washing to remediate the soil can be used though it is costly (Pilon-Smits 2005).

\section{Declarations}

\section{Acknowledgement}

I want to express my heartfelt gratitude to my Supervisors, Dr. Justin Maghanga and Dr. Mary Nelima, for their support, encouragement, and advice during my research. I would also like to express my appreciation to CEMEREM (Centre of Excellence for Mining, Environmental Engineering, and Resource Management) and DAAD (The German Academic Exchange Service) for offering me a scholarship. 
Additionally, I would like to extend thanks to Miss Magdalene Wangui and Mr. Vincent Osebe from the Ministry of Mining (Madini House), who assisted me during sample analysis.

\section{References}

1. Amos RT, Blowes DW, Bailey BL et al (2015) Waste-rock hydrogeology and geochemistry. Appl Geochemistry 57:140-156. https://doi.org/https://doi.org/10.1016/j.apgeochem.2014.06.020

2. Bernd G. Lottermoser (2011) Mine Wastes

3. Bett AK, Onyango JA, Maranga SM, Rop BK (2016) Quality of Iron ores in Kenya; TharakaNithi and Samia. 4-6

4. Bett G, Baru KJ, Kabugu M, Rop BK (2014) Beneficiation of Iron Ore in Kishushe for the Steel Manufacturing Plant. 5:7-11

5. Cheneket BK (2018) Impact Of Iron Ore Mining On Heavy Metal Concentration In Soils Of Kishushe Area In Wundanyi, Taita Taveta County

6. David Meehan (2012) Life Cycle of a Mine

7. Dias BM, Velázquez VF, Lucena RF, Azevedo Sobrinho JM (2020) Petrographic Microscope Digital Image Processing Technique for Texture and Microstructure Interpretation of Earth Materials. Earth Sci Res 9:58. https://doi.org/10.5539/esr.v9n1p58

8. Ferreira H, Leite MGP (2015) A Life Cycle Assessment study of iron ore mining. J Clean Prod 108:1081-1091. https://doi.org/https://doi.org/10.1016/j.jclepro.2015.05.140

9. Hudson-Edwards KA, Dold B (2015) Mine waste characterization, management and remediation. Minerals 5:82-85. https://doi.org/10.3390/min5010082

10. ISO (2017) International Standard ISO: Iron ores - Experimental methods for checking the precision of sampling, sample preparation and measurement Minerais. 2017

11. Jamieson HE (2011) Geochemistry and mineralogy of solid mine waste: Essential knowledge for predicting environmental impact. Elements 7:381-386. https://doi.org/10.2113/gselements.7.6.381

12. Jamieson HE, Walker SR, Parsons MB (2015) Mineralogical characterization of mine waste. Appl Geochemistry 57:85-105. https://doi.org/https://doi.org/10.1016/j.apgeochem.2014.12.014

13. Jelenová H, Majzlan J, Amoako FY, Drahota P (2018) Geochemical and mineralogical characterization of the arsenic-, iron-, and sulfur-rich mining waste dumps near Kaňk, Czech Republic. Appl Geochemistry 97:247-255. https://doi.org/https://doi.org/10.1016/j.apgeochem.2018.08.029

14. Kirsimäe EPINK (1999) Atmospheric oxidation of the pyritic waste rock in Maardu, Estonia. 1 field study and modelling. 1-19

15. Knorr K, Bornefeld M (2005) Analysis of Iron Ore - A combined XRD, XRF and MLA study Iron. Process Mineral 2012 2-3. https://doi.org/10.13140/2.1.1576.5445

16. Langhoff N, Simionovici AS, Arkadiev VA, Erko A (2006) Handbook of Practical X-Ray Fluorescence Analysis. Handb Pract X-Ray Fluoresc Anal. https://doi.org/10.1007/978-3-540-36722-2 
17. Lascelles D (2011) Bedded martite/microplaty hematite- ore genesis: environmental evolution in the Palaeoproterozoic era

18. Lottermoser B, Lottermoser B (2003) Introduction to Mine Wastes. Mine Wastes 1-30. https://doi.org/10.1007/978-3-662-05133-7_1

19. Luo L, Zhang Y, Bao S, Chen T (2016) Utilization of Iron Ore Tailings as Raw Material for Portland Cement Clinker Production. Adv Mater Sci Eng 2016:1596047. https://doi.org/10.1155/2016/1596047

20. Maranga M, Bett AK, Ndeto K, Bett G (2013) Kenyan Iron Ore: Mining and prospects of processing

21. Nordstrom DK (2011) Mine waters: Acidic to circumneutral. Elements 7:393-398. https://doi.org/10.2113/gselements.7.6.393

22. Parbhakar-Fox A, Fox N, Hill R et al (2018) Improved mine waste characterisation through static blended test work. Miner Eng 116:132-142. https://doi.org/https://doi.org/10.1016/j.mineng.2017.09.011

23. Pilon-Smits E (2005) Phytoremediation. Annu Rev Plant Biol 56:15-39

24. Rea SM, McSweeney NJ, Dwyer RB, Bruckard WJ (2015) 13 - Application of biotechnology in iron ore beneficiation. In: Lu L (ed) Iron Ore. Woodhead Publishing, pp 373-391

25. Roller J (2011) X-ray diffraction. PEM Fuel Cell Diagnostic Tools 289-313. https://doi.org/10.1201/b21371-10

26. Shrimali K, Jin J, Hassas BV et al (2016) The surface state of hematite and its wetting characteristics. J Colloid Interface Sci 477:16-24. https://doi.org/https://doi.org/10.1016/j.jcis.2016.05.030

27. Siljander M, Adero N, Gitau F, Nyambu E (2019) Land-use land-cover classification for the iron mining site of Kishushe. A feasibility study of traditional and machine learning algorithms, Kenya

28. Ssenku J, Ntale M, Backeus I, Oryem-Origa H (2017) Phytoremediation Potential of Leucaena leucocephala (Lam.) de Wit. for Heavy Metal-Polluted and Heavy Metal-Degraded Environments. In: Phytoremediation Potential of Bioenergy Plants. pp 189-209

29. Suleman HA, Baffoe PE (2017) Selecting Suitable Sites for Mine Waste Dumps Using GIS Techniques at Goldfields, Damang Mine. Ghana Min J 17:9-17

\section{Figures}




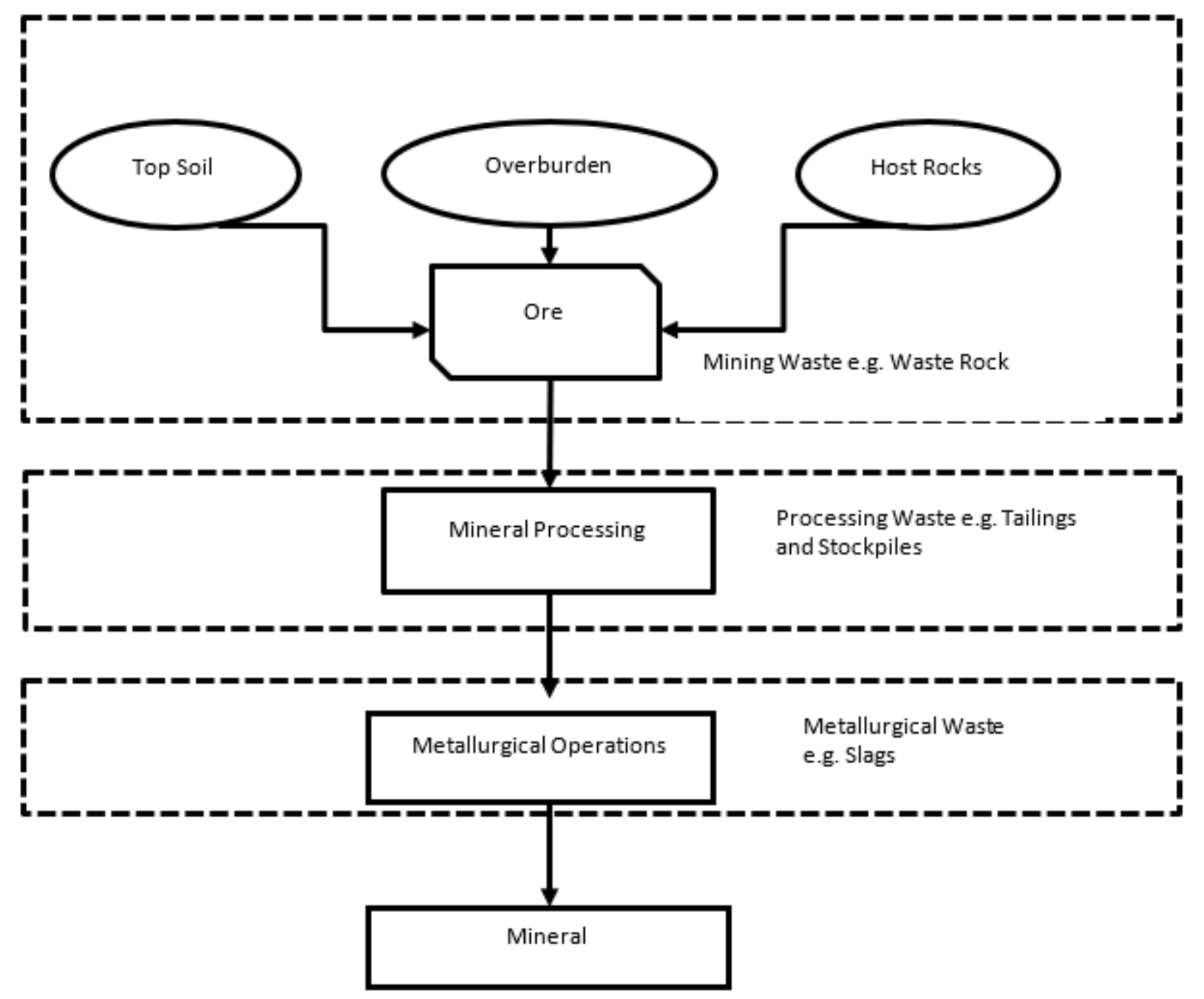

Figure 1

Waste Stream in the mining industry 


\section{^}
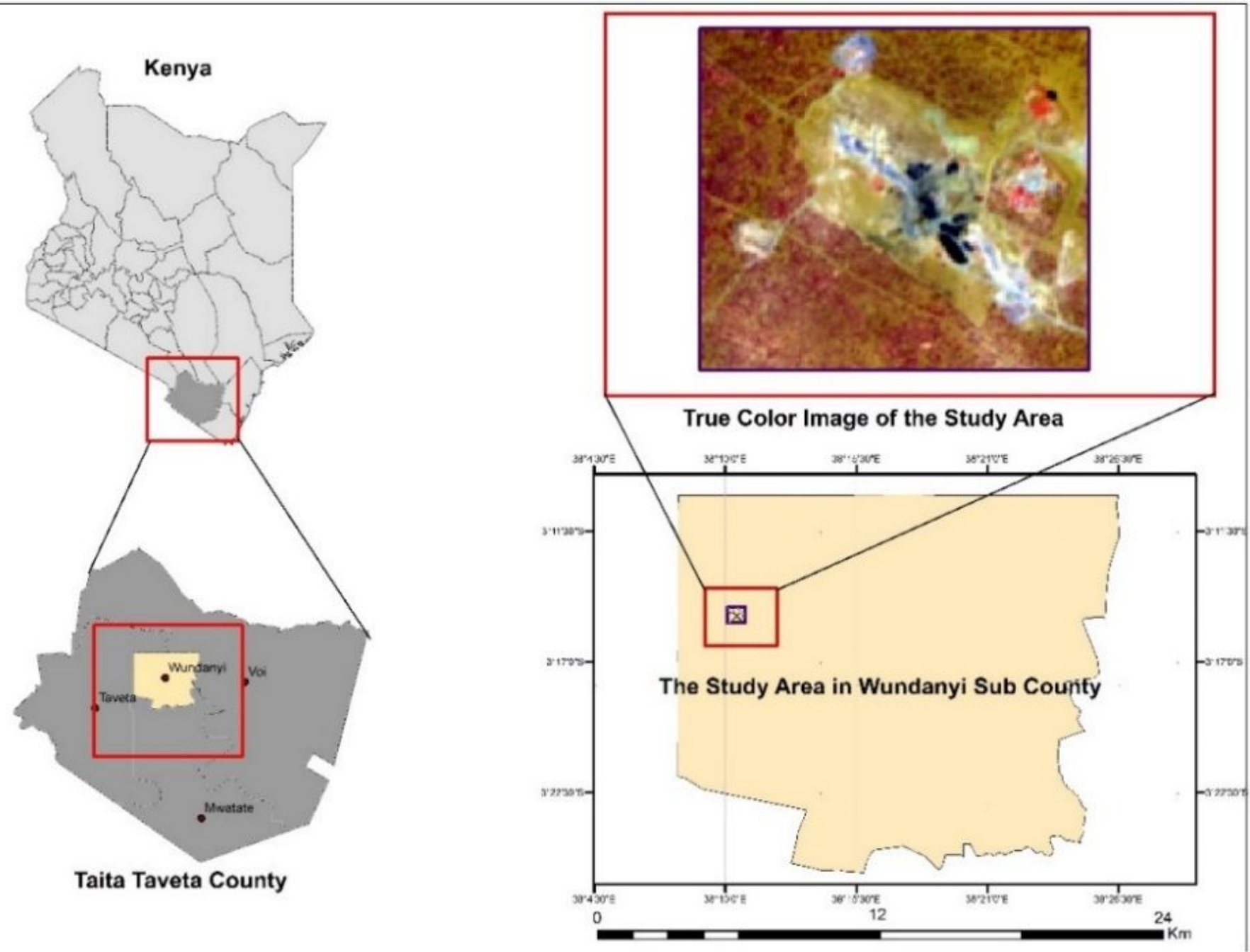

Figure 2

Map of the Study Area: Samrudha Resources, Taita Taveta County, Kenya 


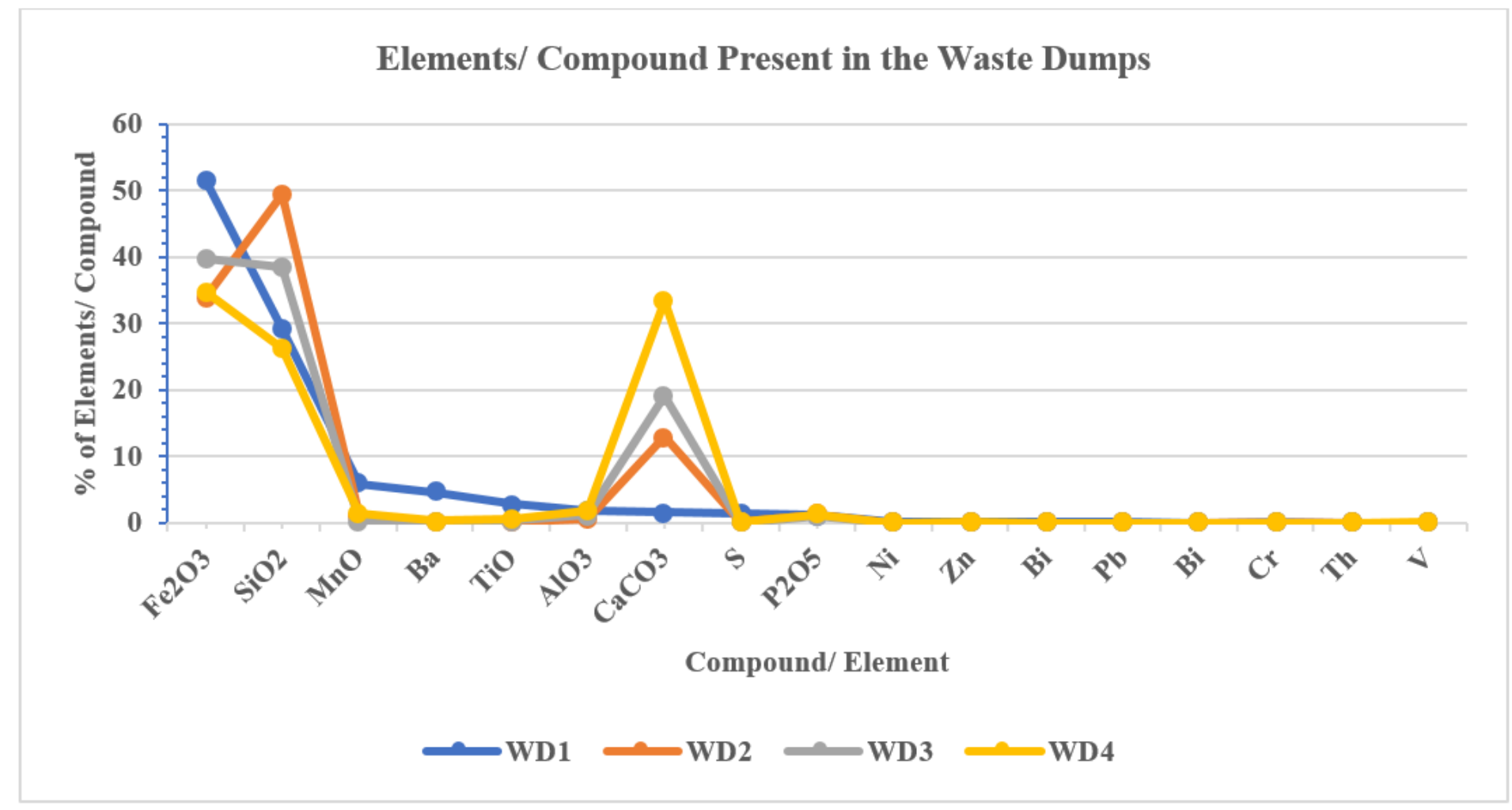

Figure 3

Waste dump samples showed high amounts of Fe2O3 (Avg. 39.92\%) and moderate amounts of SiO2 (Avg.35.9\%) and CaCO3(Avg. 16.8) with minor amounts of Vanadium (0.01\%) and Bismuth (0.01\%) 


\section{Elements/ Compound Present in the Stockpiles}

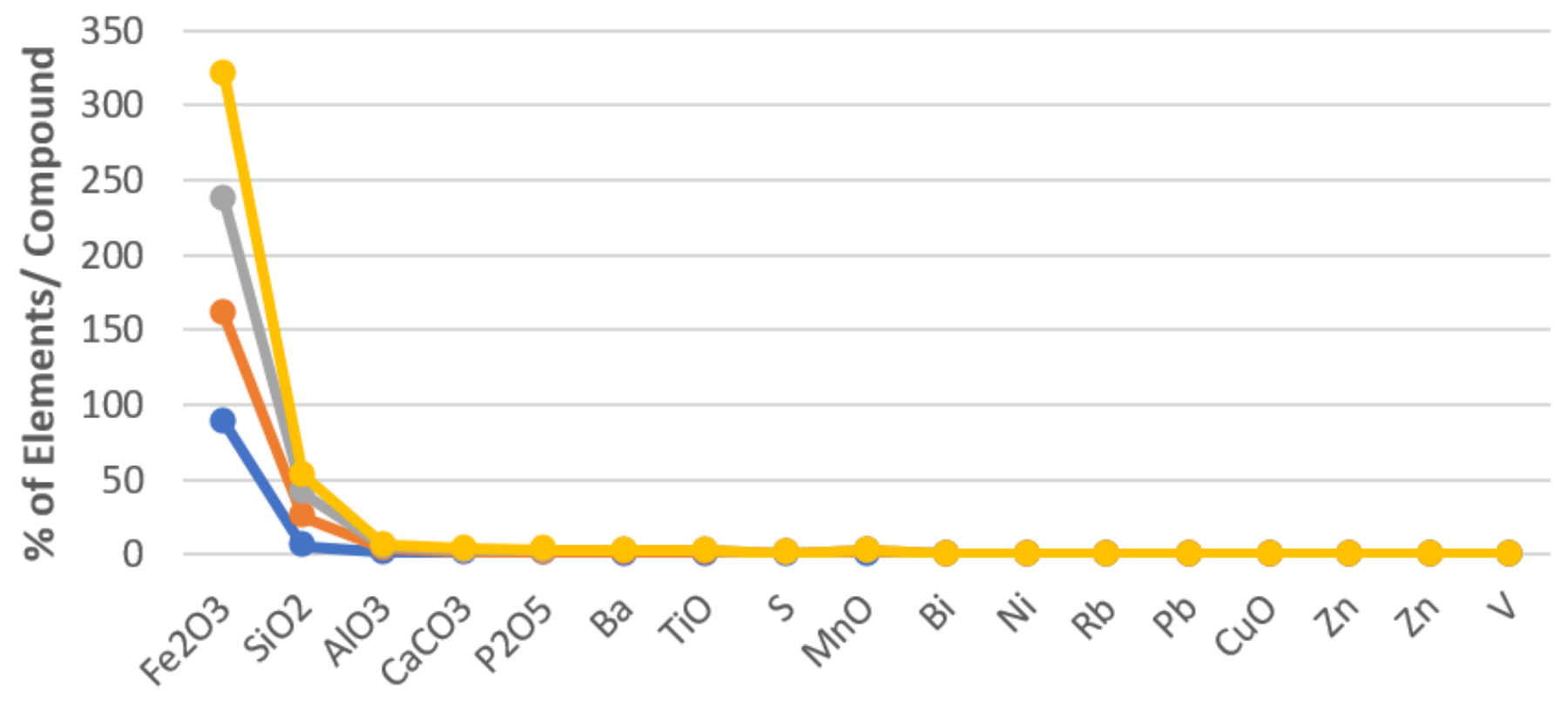

Compound/ Element

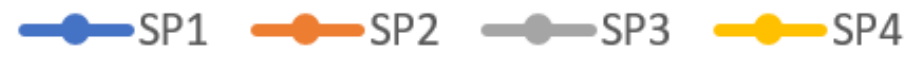

\section{Figure 4}

Stockpile Samples showed high amounts of Fe2O3 (Avg. 80.5\%) and moderate amounts of SiO2 (Avg.13.3\%) and AlO3 (Avg.1.7) with minor amounts of Zirconium (Avg. 0.0025\%) and Vanadium (Avg. $0.005 \%)$ 


\section{Elements/ Compound Present in the Overburden}

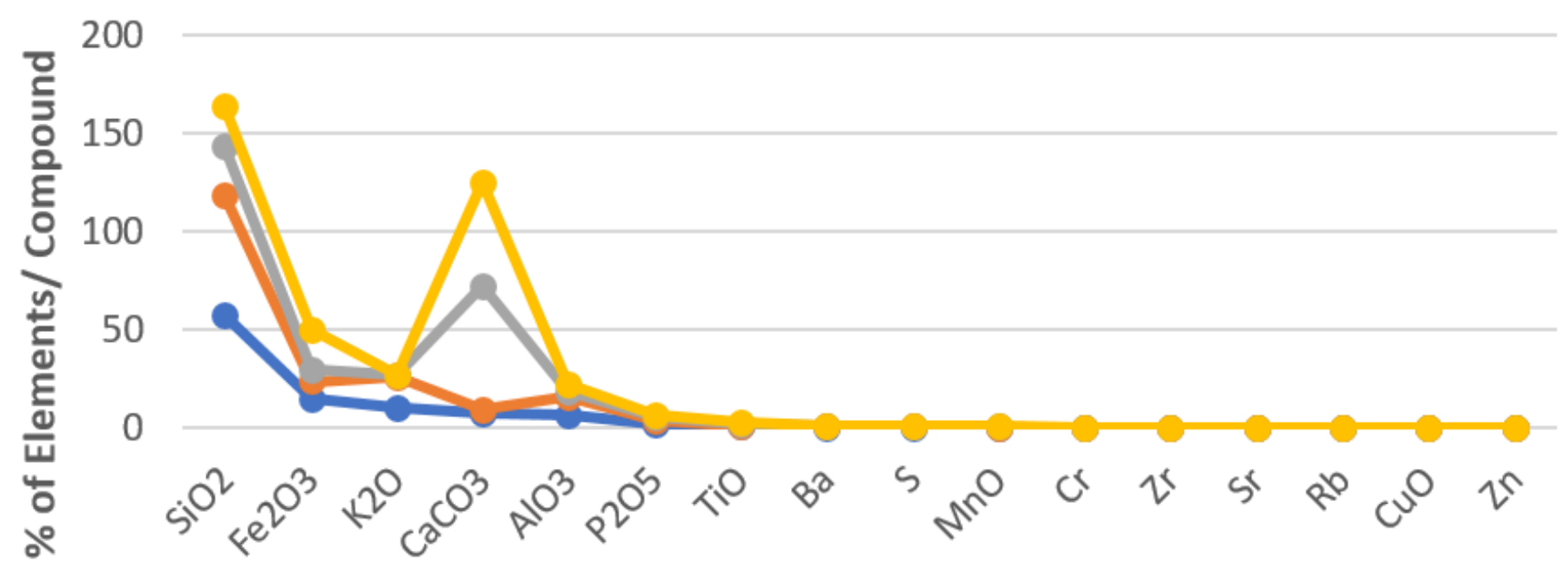

Compound/ Element

$\longrightarrow$ OB1 $\longrightarrow$ OB2 - OB3 - OB4

Figure 5

Stockpile Samples showed high amounts of SiO2 (Avg.41.02\%) and moderate amounts of $\mathrm{CaCO} 3$ (Avg.31.1\%) and Fe2O3 (Avg. 12.44\%) with minor amounts of Zinc (Avg. 0.0075\%) and Rubidium (Avg. $0.0175 \%)$ 


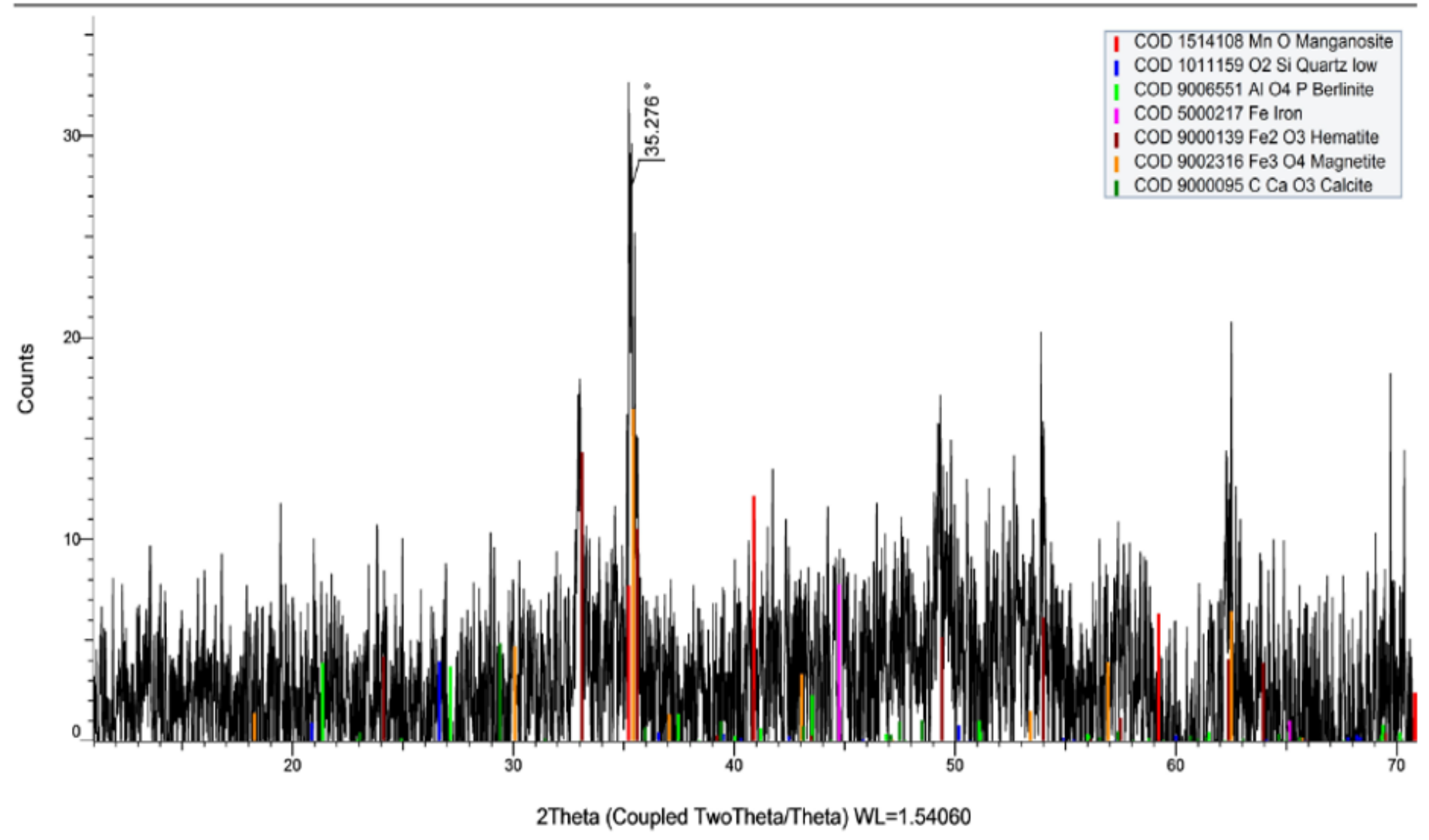

Figure 6

XRD analysis for Stockpile Sample revealed high phases of Hematite (Fe2 O3), considerable amounts of Manganosite (Mn O) and Berlinite (Al O4 P), and low quantities of Quartz (Si O2 ) minerals. 


\section{(Coupled TwoTheta/Theta)}

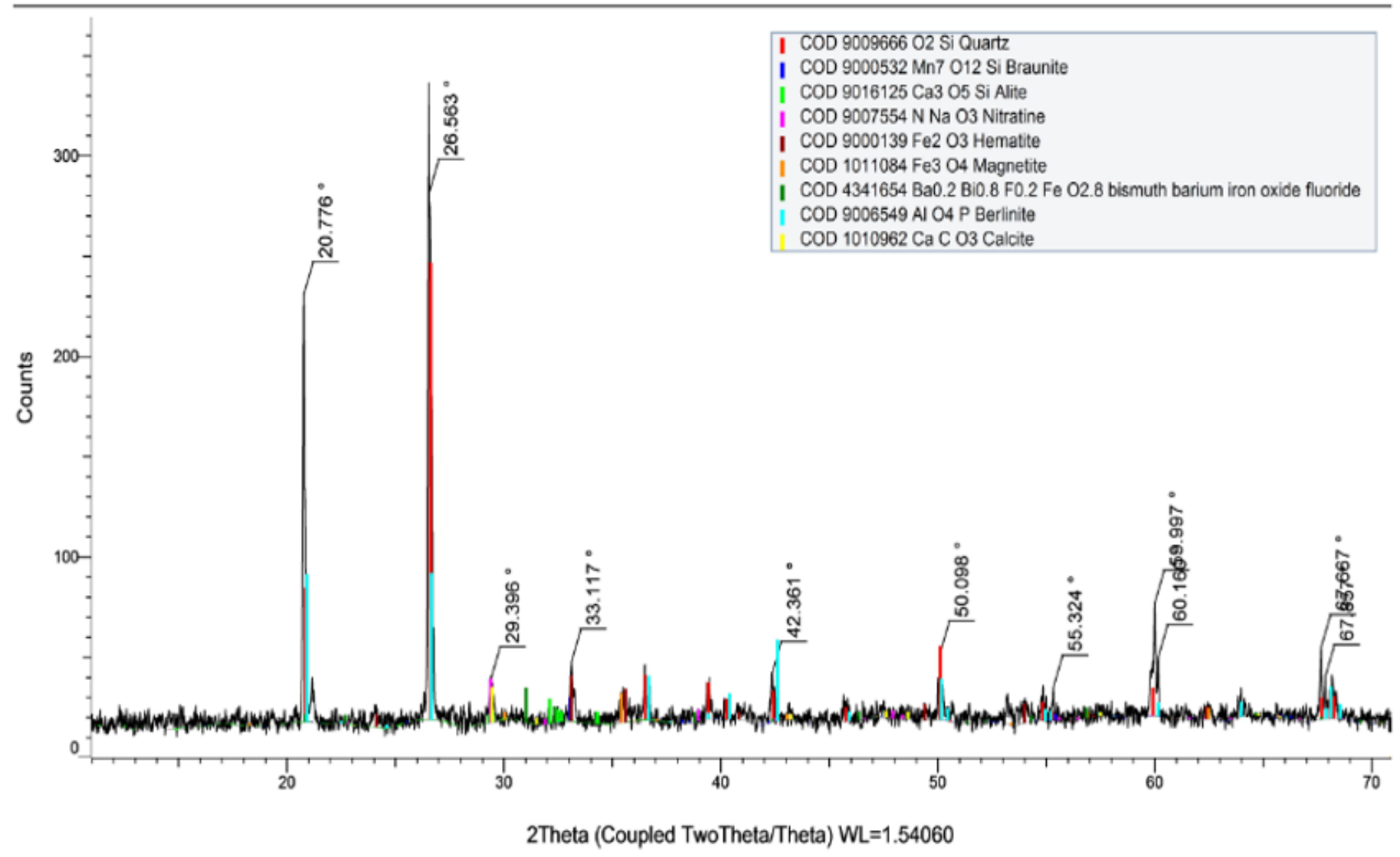

\section{Figure 7}

XRD analysis for Waste Dump Sample revealed high phases of Quartz and low phase of Braunite mineral. 


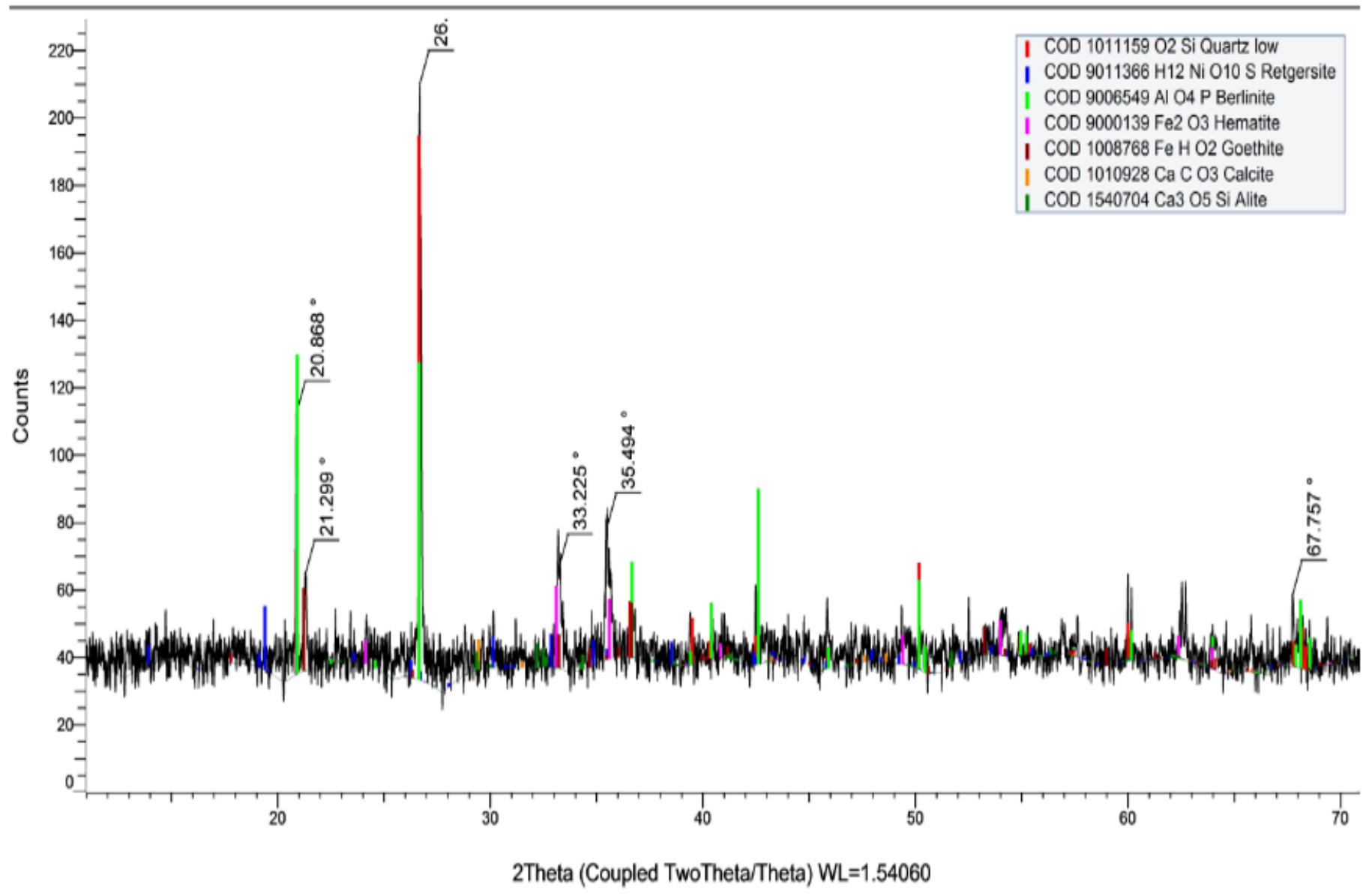

Figure 8

XRD analysis for Overburden Sample showed high phase of Berlinite, considerable phases of Retgersite and Goethite, and low phase of Hematite and Calcite. 


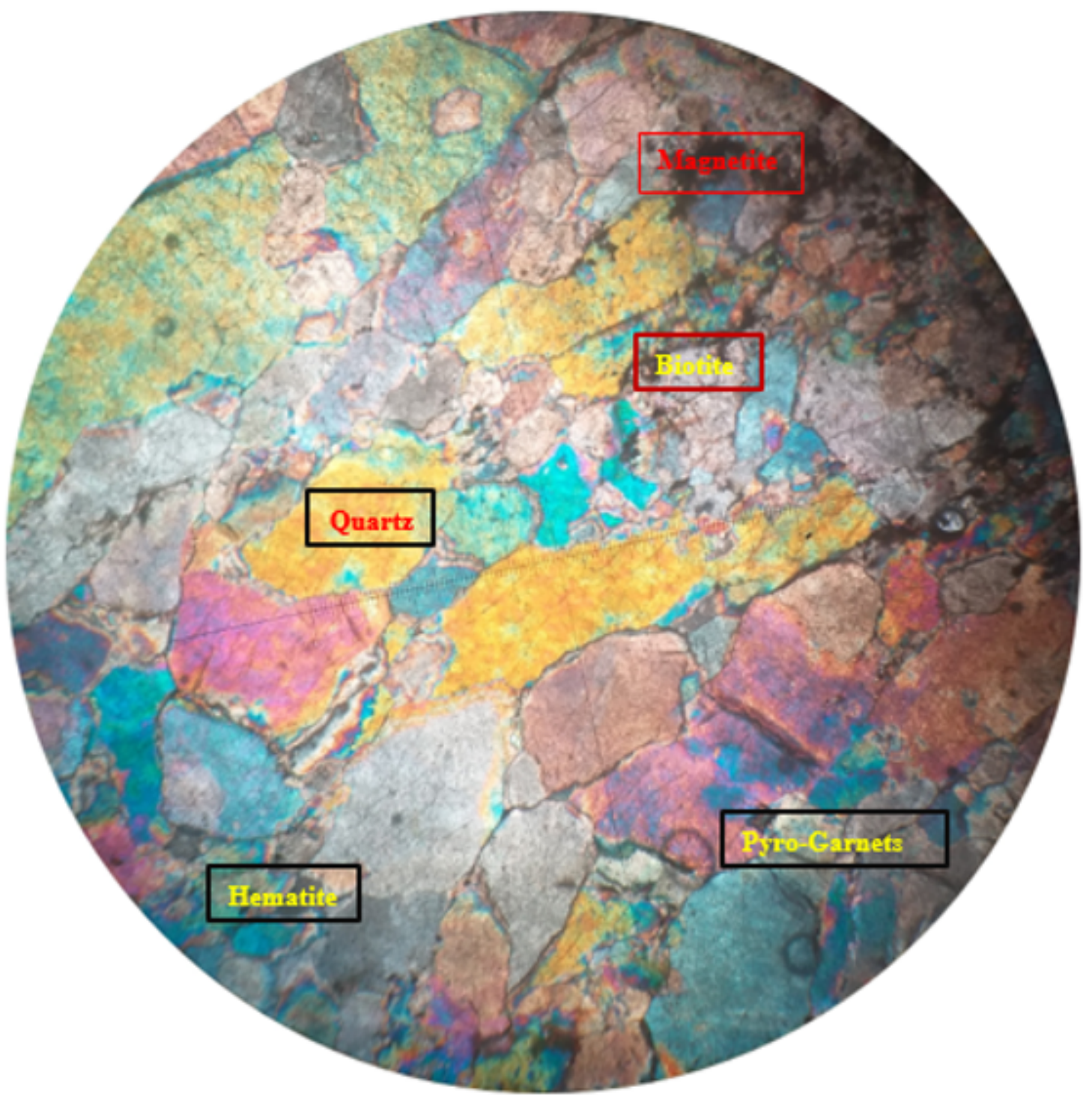

Figure 9

Thin section of Stockpile Sample 2 in X.P.L. 


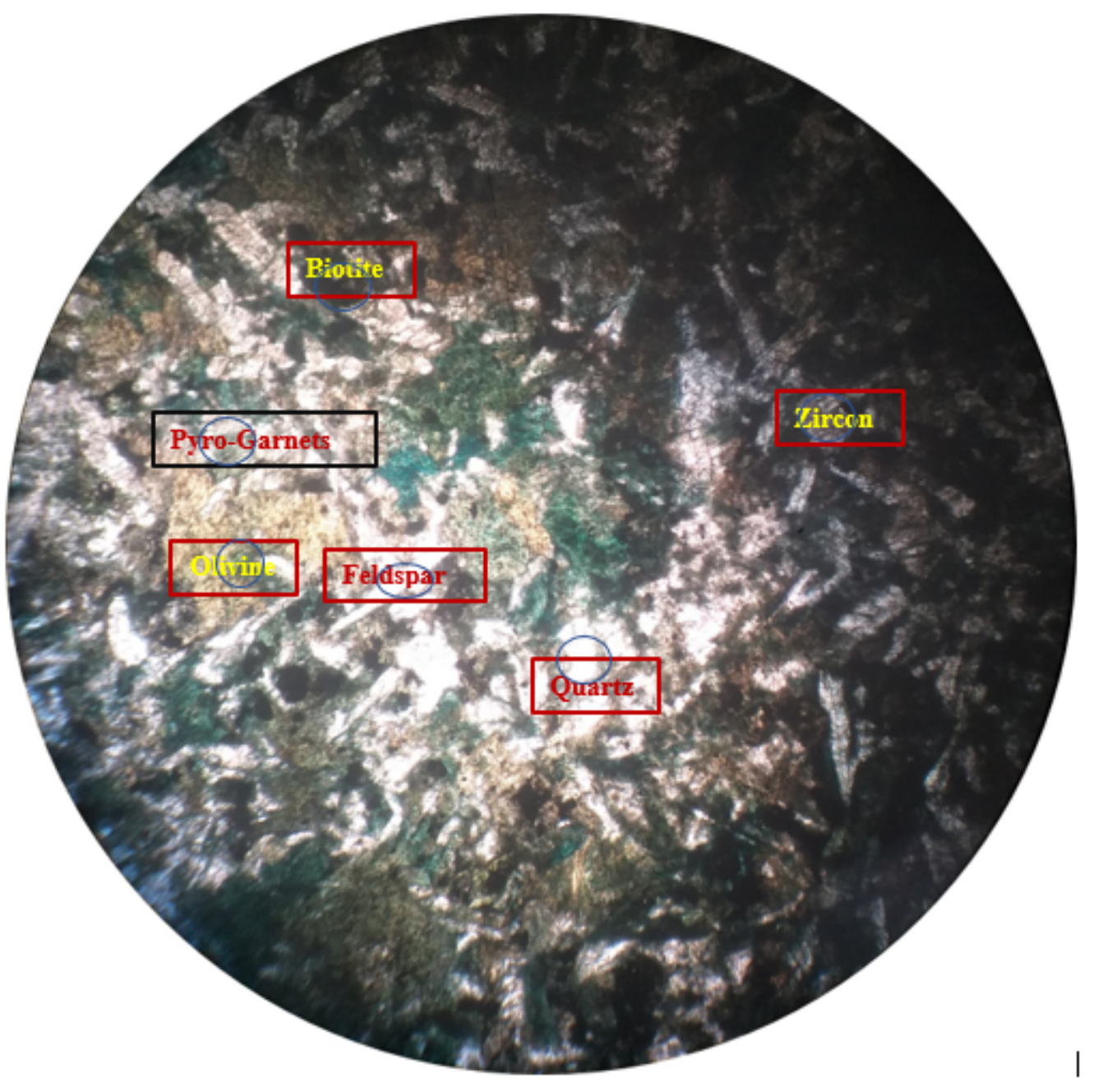

Figure 10

Thin section of waste dump Sample in PPL 


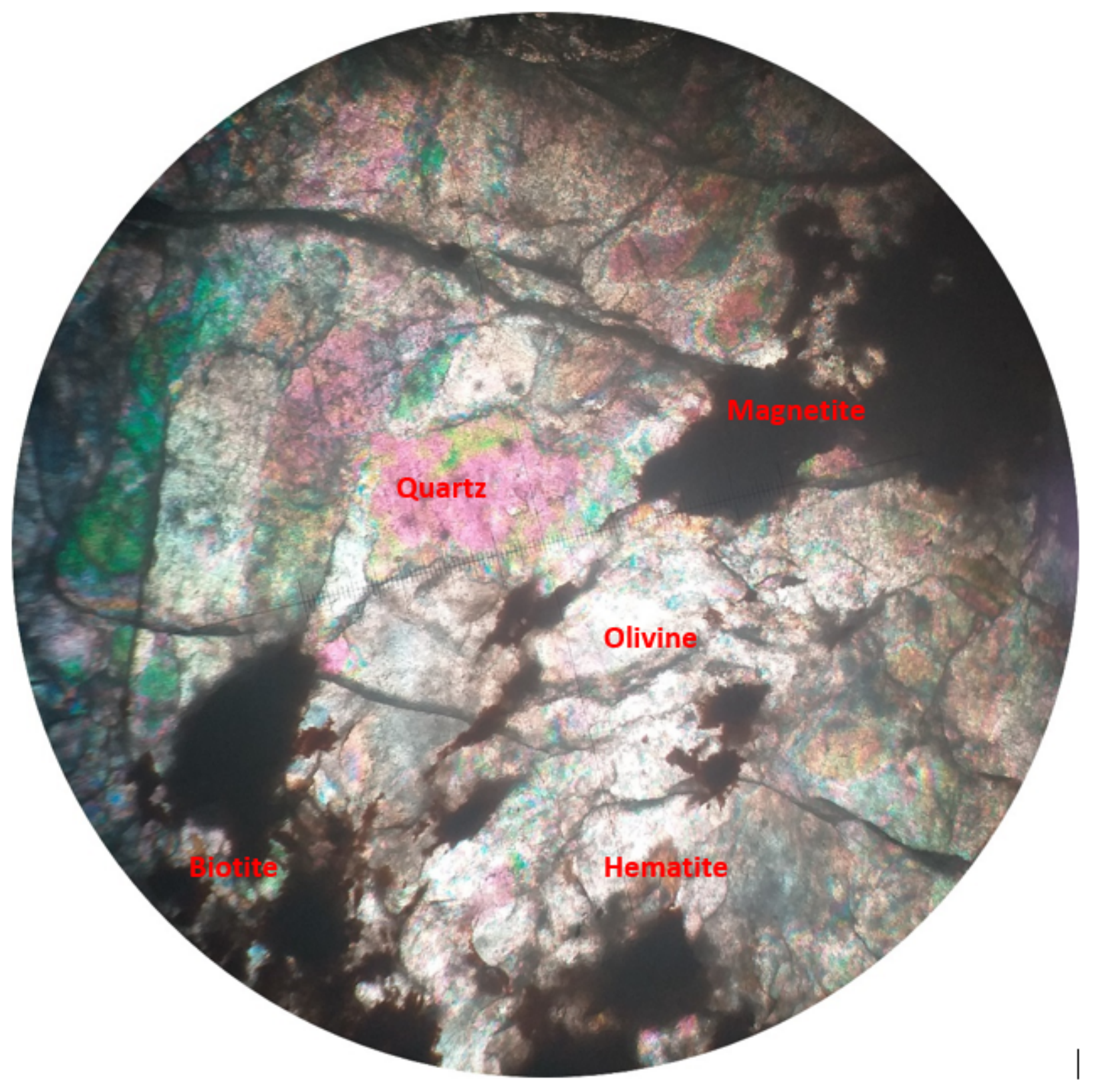

Figure 11

Thin section of Stockpile Sample 3 in X.P.L. 


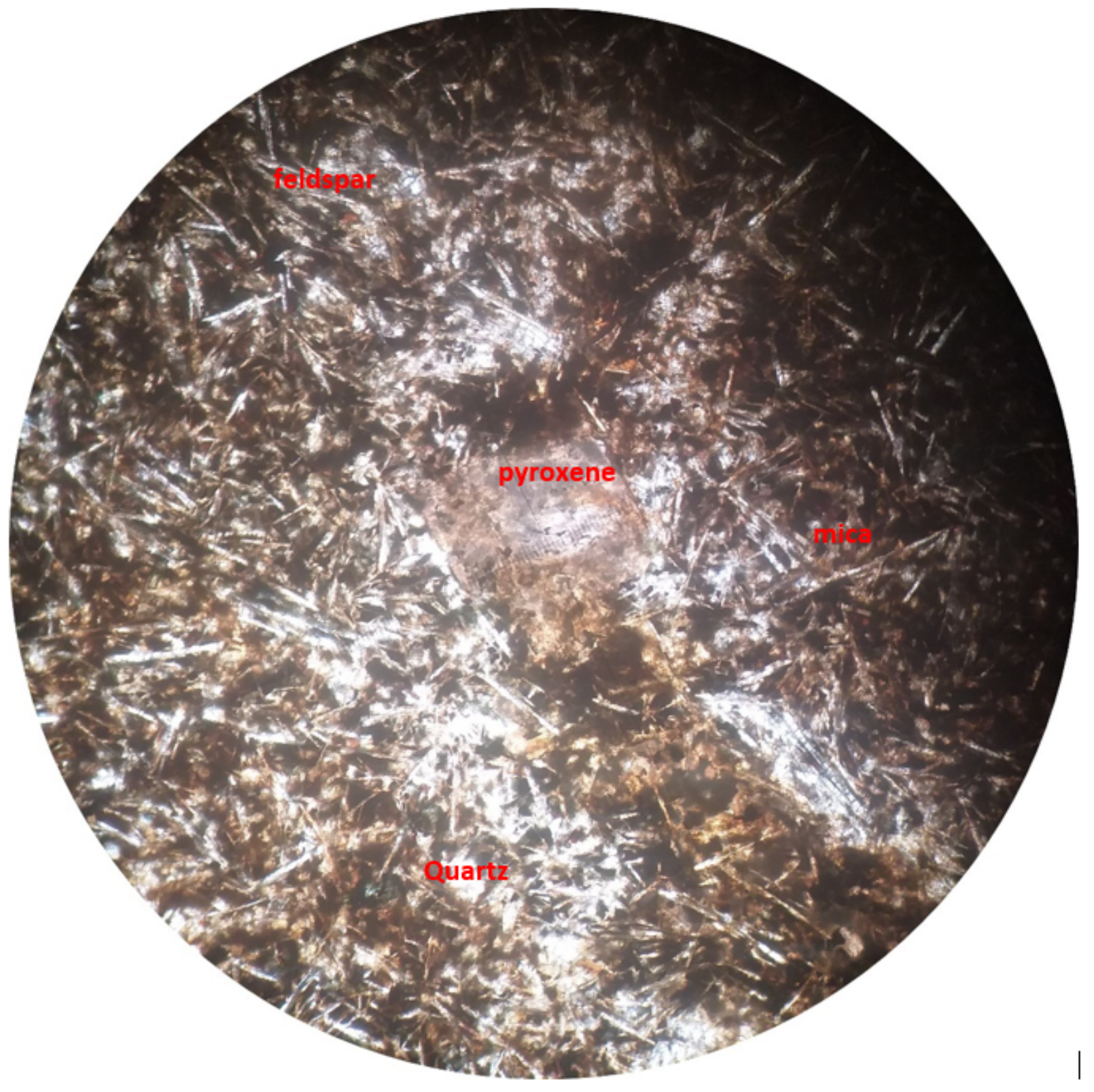

Figure 12

Thin section of Overburden material (O.B. 4) in X.P.L. 


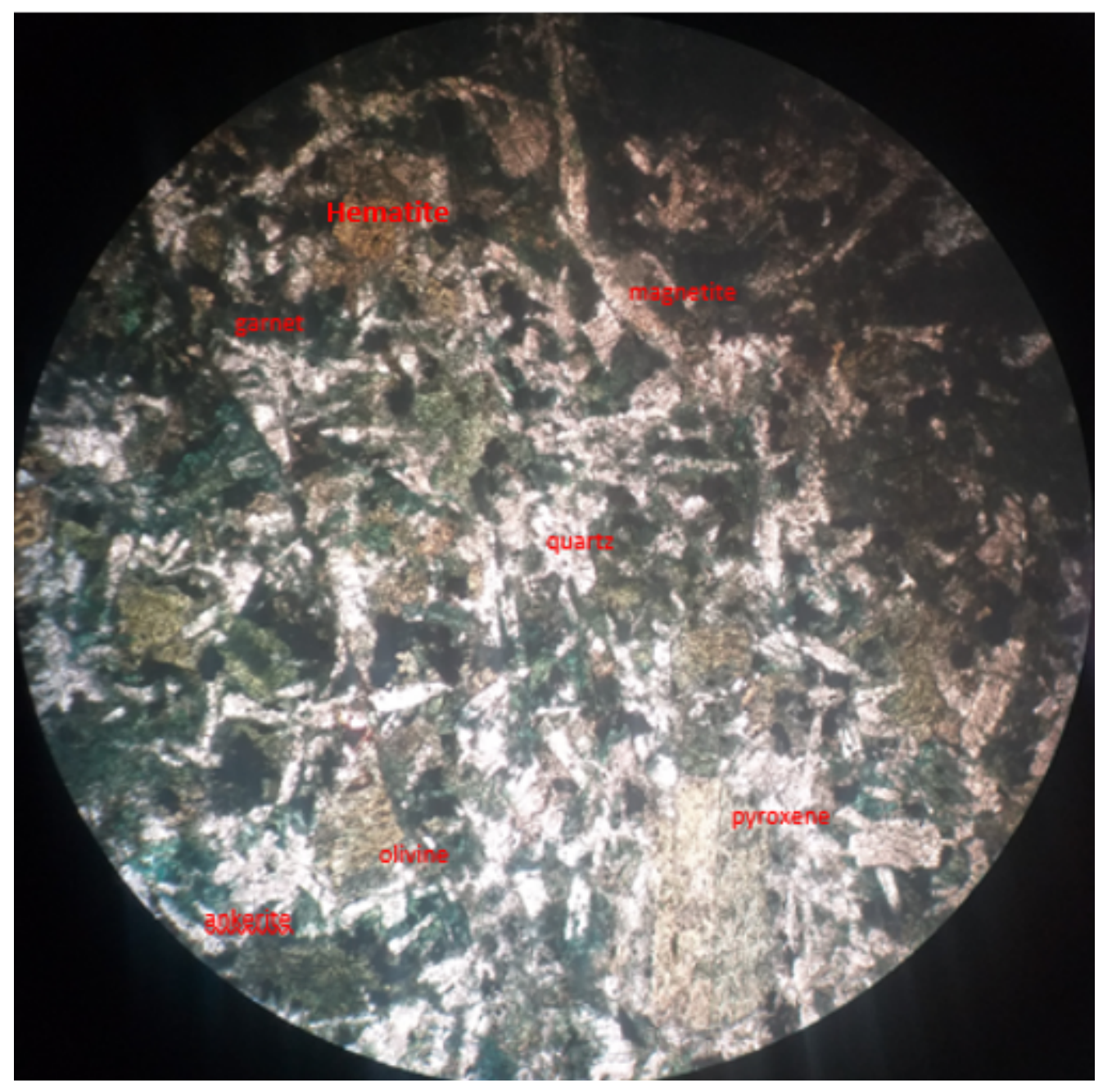

Figure 13

Thin section of Stockpile 1 (S.P. 1) in PPL 